\title{
The Political Economy of Monetary Institutions
}

\author{
William Bernhard, J. Lawrence Broz, and \\ William Roberts Clark
}

\section{Introduction}

Why do national governments choose the monetary institutions they do? While this question has long interested political economists, previous literature on the topic suffers from a central limitation: the choices of exchange-rate regime and central bank independence (CBI) have been analyzed in isolation from one another. This is surprising given that prominent arguments from this literature portray these institutions as solutions to the same problem-the time-inconsistency of monetary policy, or the inability of policymakers to commit credibly to staying the course on an announced policy.

Time-inconsistency means that policymakers have an incentive to announce low inflation policies and then renege on that promise to achieve short-term improvements in real economic outcomes - growth and employment. Since private actors anticipate this behavior, attempts to create inflationary surprises will be frustrated, producing no additional growth and higher inflation. The best the policymaker can hope for is to make the promise of low inflation credible. CBI and fixed exchange rates have each been held out as ways of increasing the credibility of ex ante policy announcements and thereby reducing the inflationary bias of monetary policy. Both institutions insulate monetary policy from the direct control of those actors thought to have the greatest incentive to increase growth through ex post opportunismincumbent politicians.

The authors wish to thank the European Union Center of the University System of Georgia and the Sam Nunn School of International Affairs at The Georgia Institute of Technology for their kind support of a conference entitled "Explaining Monetary Commitment Technologies: The Political Foundations of EMU" that took place in Atlanta on 1 September 1999. The seeds of the current volume, and a number of the included papers, were planted at that conference. We are also grateful to conference participants and the contributors to this volume, particularly David Andrews, Benjamin Cohen, Kathleen McNamara, Robert Franzese, and Thomas Willett for the comments then and during the evolution of this project. In addition, we thank the current and past editors, Lisa Martin, Peter Gourevitch, and David Lake, and two anonymous reviewers for their helpful comments. 
The argument that these institutions are chosen as a response to the same economic problem raises several issues about how we analyze the determinants of monetary institutions. First, while the inflationary bias of discretionary policy creates the need for credible commitment mechanisms, it does not explain why some countries address the problem with fixed exchange rates, some choose independent central banks, some both, and some neither. Even if exchange rate anchors and central bank rules were unproblematic solutions to the inflationary bias in monetary policy, we still must explain how nations choose between the two solutions.

Second, we are not likely to understand the conditions under which exchange rate or central bank anchors are adopted if we study the choice of each institution in isolation. To learn whether CBI and fixed exchange rates are institutional substitutes (where the presence of one negates the need for another) or complements (where each reinforces the effect of the other), we must develop an approach that considers their joint determination. Modeling the choice of one monetary commitment without an explicit consideration of the benefits and costs of the other does not shed light on this important question.

Third, it may be the case that the time-inconsistency framework does not capture how political actors evaluate the benefits and costs of different monetary arrangements. The choice of these institutions may have less to do with fighting inflation than with the desire to redistribute real income to powerful constituents, assemble an electoral coalition, increase the durability of cabinets, or engineer economic expansions around elections. While the time-inconsistency framework informs much of the work in this volume, we may need to move beyond it to incorporate factors that influence the opportunity costs of adopting alternative monetary institutions.

The contributors to this volume respond to these challenges. They explicitly analyze the choice of both exchange-rate regime and central bank institutions together. They emphasize how political factors, such as electoral, partisan, or sectoral pressures, influence the combination of monetary institutions that governments adopt. They seek to determine how politics conditions the opportunity costs of different configurations of monetary commitments. By analyzing the choice of both exchange rate regime and central bank institutions, they identify the conditions under which these institutions function as substitutes or complements. Finally, the contributors not only build on the time-inconsistency framework, but also confront its assumptions and implications, giving us a better understanding of the motivations of different actors in the process of choosing monetary commitments.

In the next section, we summarize the range of institutional outcomes to be explained, highlighting those factors that would be difficult to explain from a pure time-inconsistency framework. We then show that the logic of time-inconsistency is nonetheless the analytical thread uniting the disparate work on central banking and exchange-rate regimes in the existing economics literature, justifying our treatment of the institutions as jointly determined. In the following section, we review "firstgeneration" explanations for these outcomes-explanations that incorporate both economic and political factors but look at CBI and exchange-rate regimes as 
isolated, independent decisions. We then highlight ways in which the "secondgeneration" contributors to this volume gain explanatory advantages by analyzing both sets of institutions concurrently. While each contributor has a slightly different approach, argument, and evidentiary strategy, each examines the choice of monetary institutions in combination. In the final section, we present our conclusions.

\section{Monetary Institutions Since Bretton Woods}

Over the past thirty years, countries have pursued a variety of monetary arrangements and commitments. These experiments involve two distinct types of monetary institutions: central banks and exchange-rate regimes. Central banks are the bureaucratic institutions charged with managing the supply of credit to the economy. The institutional structure of central banks - that is, their degree of independence from direct government control-varies across systems and over time. When a central bank is completely "dependent," its institutional structure permits the government to determine monetary policy directly. With a fully independent central bank, by contrast, the government delegates monetary policy to an agent-typically the central bank's governing board - and is restricted by statute from interfering with the agent's freedom of action in the monetary domain.

Countries have also adopted a variety of exchange rate arrangements, ranging from a purely floating-exchange-rate system, where market forces determine currency values, to an irrevocable exchange-rate peg or common currency among countries. ${ }^{1}$ While exchange-rate regimes are usually distinguished by the degree of flexibility in the arrangement (from a free float to an immutable fix), regime choice also involves a delegation decision not unlike that which governments face when setting the level of CBI. When a nation fixes its currency's value to that of another nation, it is, to a large extent, delegating monetary policy to a foreign central bank. The pegging nation not only forgoes exchange-rate flexibility as a policy tool, but it also subordinates its monetary policy to that of the foreign central bank.

Notwithstanding important differences between the two institutions, exchangerate pegs and CBI can be thought of as alternative forms of monetary delegation. Indeed, as we shall discuss, a purely economic logic of monetary delegation, derived from the problem of time-inconsistent policy pronouncements, applies with roughly equal force to both $\mathrm{CBI}$ and pegging.

In practice, countries often adopt intermediate institutions that fall between the extremes: cases of completely independent or dependent central banks are as rare as cases of pure floating or perfectly fixed exchange-rate regimes. Political economists have employed a variety of methods to measure the level of CBI and the degree of flexibility in exchange-rate arrangements. The most common indicators are based on formal or legal characteristics. With CBI, this typically entails an examination of

1. Broz and Frieden 2001. 
central bank statutes, with an emphasis on restrictions of the government's policy influence. Common legal indicators of independence include procedures for the appointment, term duration, and dismissal of central bank directors; budgetary autonomy for the central bank; government veto power over monetary policy; explicit policy goals; performance incentives for bank directors; limitations on monetary financing of budget deficits; and control over monetary instruments. ${ }^{2}$ Most indices combine these factors to produce a one-dimensional scale of CBI. Although each scale emphasizes slightly different factors, they are often in relative agreement about the ranking of CBI across systems. ${ }^{3}$

Indicators of exchange-rate arrangements are usually based on nations' formal commitments, as reported to, or observed by, the International Monetary Fund (IMF). As with CBI, these arrangements fall along a continuum. Indeed, the IMF's Exchange Arrangements and Exchange Restrictions recognizes no fewer than nine different types of exchange-rate regimes, varying according to the degree of flexibility in the arrangement.

Formal and legal measures, although readily observable, may not capture a nation's actual institutional commitments. For example, a statutorily independent central bank may be subject to extensive informal pressures from government. Recognition of this problem has propelled research on the "behavioral" independence of central banks and on the actual adherence to exchange-rate commitments. Alex Cukierman, for example, developed a behavioral measure of CBI based on the average term of office of central bank governors. ${ }^{4}$ According to Cukierman's logic, a high "turnover rate" in central bank leadership reflects an absence of independence. However, a number of scholars have pointed out that a subservient central banker might be able to stay in office forever.

With respect to exchange-rate regimes, there also appears to be a gap between formal commitments and the extent to which these commitments are honored in practice. Many countries that purport to float intervene heavily on foreign exchange markets. ${ }^{5}$ Likewise, many countries that formally maintain fixed regimes do in fact make frequent adjustments to exchange parities. ${ }^{6}$ Although the measurement of actual monetary commitments remains a problem, available data indicate that countries' commitments are extremely varied, both across countries and over time. This holds for levels of CBI, the propensity to fix exchange rates, and various combinations of these two institutions. We now discuss some stylized facts that remain unexplained from a simple time-inconsistency perspective.

2. See Alesina 1988; Alesina and Summers 1993; Burdekin and Willett 1991; Cukierman 1992; Cukierman, Webb, and Neyapti 1992; Eijffinger and de Haan 1996; and Grilli, Masciandaro, and Tabellini 1991.

3. Eijffinger and de Haan 1996.

4. Cukierman 1992.

5. Calvo and Reinhart 2001.

6. Obstfeld and Rogoff 1995. 


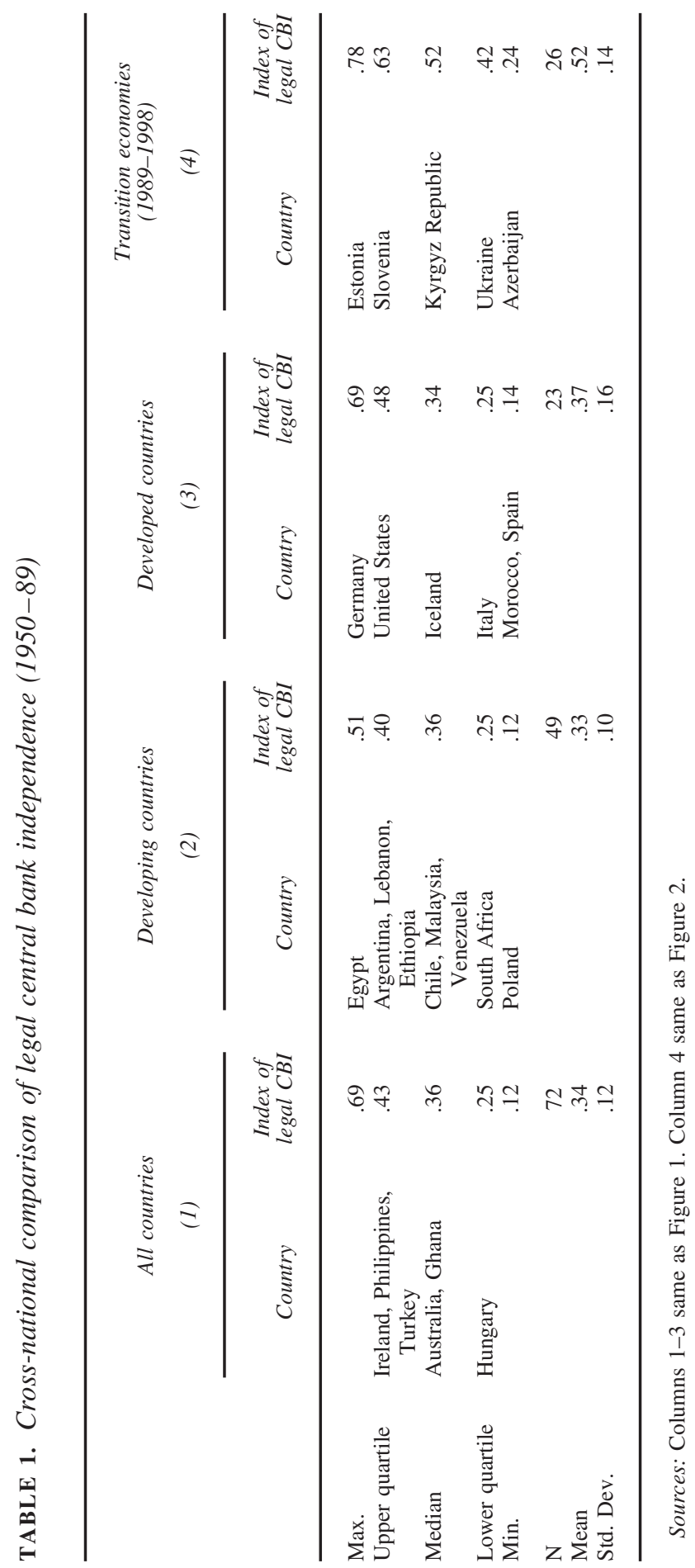




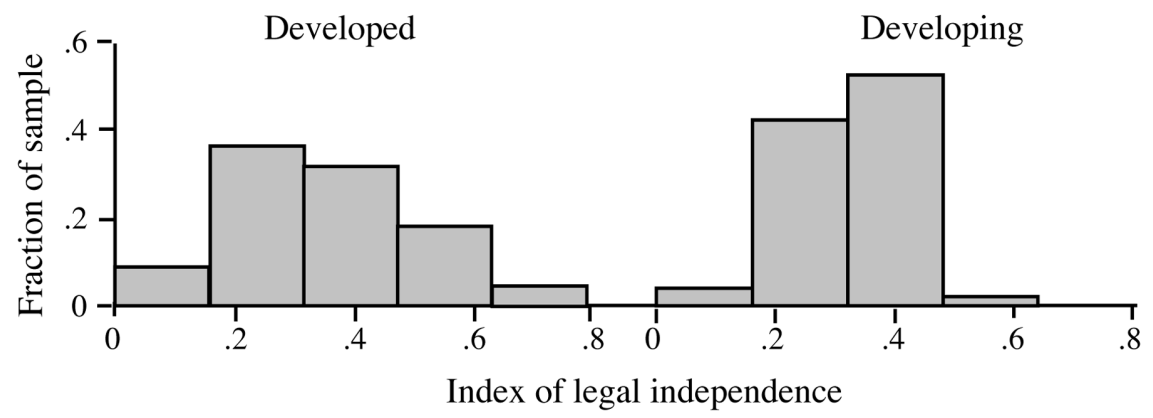

FIGURE 1. Distribution of legal indices of central bank independence in developed and developing countries

Source: Cukierman, Webb, and Neyapti 1992

\section{Variation in Central Bank Independence}

From a naively benevolent view of government decision making, one might expect little variation in CBI. If CBI yields universally desired outcomes, it should be adopted by all nations. The available evidence suggests that it is not. Table 1 provides rankings of legal CBI for seventy-two countries for the period from 1950 through 1989, based on the comprehensive and widely used scale developed by Cukierman, StevenWebb, and Bilin Neyapti. ${ }^{7}$ Column 1 provides summary statistics for the full sample, columns 2 and 3 divide the sample into developing and developed countries, respectively, and column 4 extends the sample to transition economies. It is immediately obvious that there is enormous variation in levels of formal CBI in this period. Among developed countries, the central banks of Germany and Spain are, respectively, the most and least independent central banks. Iceland is positioned at the median of the developed country sample. There is also evidence of substantial variance in legal CBI in the developing world. The outcomes range from minimal legal independence in Poland to Egypt, the developing country with the most independent central bank. Figure 1 presents the distribution of CBI for the developed and developing subsamples. While there is a wide range of CBI in both subsamples, the developing countries tend to be clustered around the center of the scale more than the developed countries.

While the cross-national variance in CBI between 1950 and 1989 is considerable, changes in $\mathrm{CBI}$ in this period were not very common. Less than half the countries in the Cukierman, Webb, and Neyapti sample experienced a change in legal independence during the period. Of the countries that reformed their central bank laws, twelve underwent a net decrease in CBI, while thirteen increased the

7. Cukierman, Webb, and Neyapti 1992. See the discussion of this and other scales in Eijffinger and de Haan 1996. 
independence of their central banks. Furthermore, the magnitude of average decreases was about as large as the magnitude of average increases (between seven and eight points on the legal index, respectively). There is little evidence of a trend toward greater independence in the period between 1950 and 1989, an outcome that might be expected if benevolent governments came to recognize the social welfare advantages of the institution.

More recently, however, such a trend may be under way. Although indices of CBI have not been systematically updated, many countries have moved to increase the independence of their central banks since the early 1990s. Among the industrial democracies, Italy and New Zealand made the earliest moves to grant their central banks more independence. The Maastricht Treaty required members of the European Union (EU) to grant their central banks formal independence as a precondition to participating in Economic and Monetary Union (EMU). France, Belgium, Spain, and other member-states quickly complied with this obligation. Outside the Eurozone, Britain (1997) and Japan (1998) also increased the independence of their central banks.

The reform trend also seems to extend beyond the industrial democracies. Cukierman, Miller, and Neyapti document high levels of legal independence in twenty-six former socialist economies after post-transition reforms. ${ }^{8}$ Column 4 of Table 1 provides some illustrative comparisons. Note that the median case (Kyrgyz Republic) has a higher degree of legal independence (0.52) than the U.S. Federal Reserve-widely considered one of the most independent central banks in the world. Indeed, eight of these newly created central banks "possess levels of aggregate legal independence which exceeds that of the highly independent Bundesbank during the 1980s."9

While legal independence measures for the 1990s in other regions are not readily available, Sylvia Maxfield reports regional averages that suggest that the increase in CBI is not unique to Eastern Europe. The regional averages for Latin America and Western Europe, for example, are 0.55 and 0.46 respectively. ${ }^{10}$ Mexico and Chile, for instance, both increased the formal independence of their central banks. ${ }^{11}$ If the central banks of the former Soviet states are any indication, however, the apparent recent trend toward CBI does not necessarily constitute cross-national convergence on a particular institutional form. As Figure 2 illustrates, while the level of independence in the former Soviet states is relatively high, there is still considerable cross-national variance in the degree of independence. Given that CBI has become a nearly ubiquitous policy prescription for economists, international agencies, and policymakers interested in improving economic performance, this variation requires explanation. In addition, the potential gap between legal and behavioral independence suggests that it is important to try to determine whether these recent increases

8. Cukierman, Miller, and Neyapti 2001.

9. Cukierman, Miller, and Neyapti 2001, 4.

10. Maxfield 1997, 51.

11. Boylan 1998. 


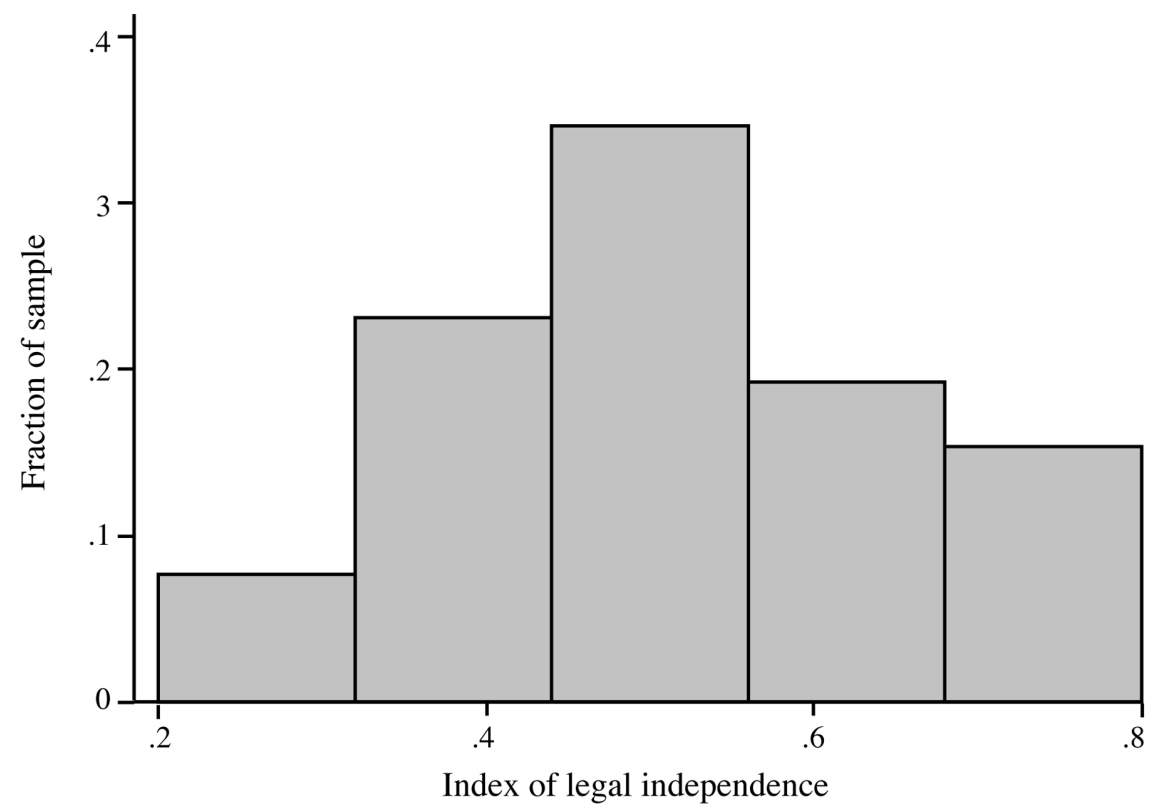

FIGURE 2. Distribution of legal central bank independence in twenty-six former Soviet economies

Source: Cukierman, Miller, and Neyapti 2001

in independence produce equilibrium institutions by examining the conditions associated with CBI in the recent past.

\section{Variation in Exchange-Rate Regimes}

At the end of World War II, Allied leaders established a set of international monetary institutions to promote global economic prosperity and international stability. A fixed exchange-rate system, where participating nations pegged their exchange rate to the U.S. dollar, was at the heart of these institutions. The United States, in turn, pledged to redeem gold for dollars at the rate of $\$ 35$ an ounce. The "Bretton Woods" system worked well in the 1950s, as the United States injected liquidity into the world economy and promoted economic recovery. But strains appeared in the 1960s, reflecting both the gold overhang-U.S. gold reserves were inadequate to cover all the dollars circulating in the world economy-and lax U.S. macroeconomic policies. European nations and Japan bridled under the regime because it tied their monetary conditions to the inflationary policies of the United States. In the early 1970s, the system collapsed as the United States declared it would no longer honor its commitment to exchange dollars for gold. 


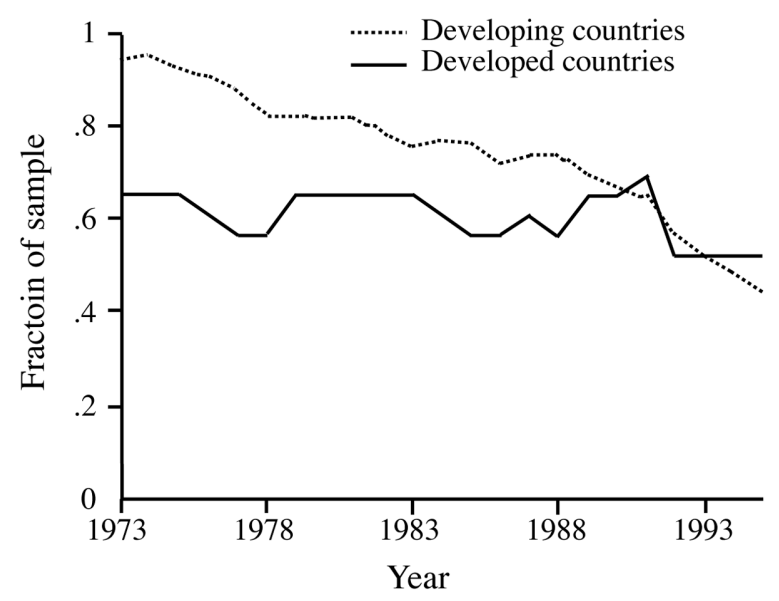

FIGURE 3. Percentage of countries adhering to fixed exchange rates

Source: Ghosh et al. 1997

The breakdown of the Bretton Woods system ushered in an era of unprecedented variety in exchange rate regimes. The currencies of the largest industrial economies (the United States, Germany, Japan, and Britain) floated against each other, and several medium-sized developed countries also floated independently (for example, Canada, Switzerland, Australia, New Zealand). In contrast, European nations quickly attempted to limit exchange rate variability in the region, first pursuing exchange rate cooperation under the European Exchange Arrangement (Snake) and later, in the European Monetary System (EMS). At the same time, some European countries outside the EMS - for example, Austria and Sweden-maintained tight pegs to the deutsche mark. Through the 1980s, the EMS hardened into a quasi-fixed exchange-rate regime for EU member states. In 1991, EU member states signed the Maastricht Treaty, committing themselves to the adoption of a single currency by 1999.

For developing countries and, later, the transition economies of the former Soviet Union, a mixture of exchange-rate regimes has prevailed, with a growing tendency for many of these countries to adopt flexible exchange-rate arrangements. Mexico, Brazil, and several Asian economies shifted toward floating exchange rates to deal with the complications of an open capital account. In contrast, other Latin American countries rigidly tied their currencies to the U.S. dollar. Argentina, for instance, established a currency board that forced domestic monetary policy to follow in lockstep the policies of the U.S. Federal Reserve. Ecuador and El Salvador have gone so far as to adopt the U.S. dollar as their national currencies-an extreme case of delegation to a foreign monetary authority.

Figure 3 shows the distribution of formal exchange-rate commitments over time, 


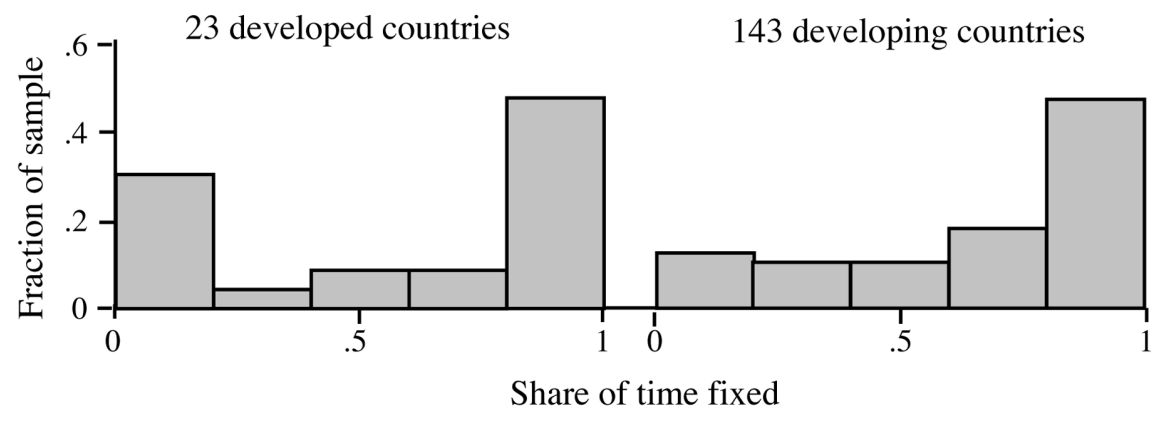

FIGURE 4. Time on fixed exchange rates, developed and developing countries, $1970-1989$

Source: Ghosh et al. 1997

as the IMF reports. About 60 percent of the 167 countries in this sample have had fixed exchange rates since 1973 . In the industrial democracies, the propensity to fix has been fairly constant; in the developing world, the trend is toward flexible exchange rates. This trend may itself obscure important regional differences. While there is a decreased propensity to peg in recent years in Latin America, Asia, Africa, and former Soviet States, countries in the Caribbean, Middle East, or the Pacific Islands have maintained fixed exchange-rate regimes. ${ }^{12}$

Further, countries have experimented with different exchange-rate arrangements over time. While many countries had fixed exchange rates for the entire sample period and other countries never made such a commitment, it was also common for countries to go on and off a peg. Figure 4 shows that the share of time a country spent with a fixed exchange rate varies considerably across countries. While the majority of countries spent the entire observation period with a commitment to a fixed exchange rate, and a fair number of countries are coded as having a "flexible" exchange rate for the entire period, many countries maintained a fixed exchange-rate arrangement for only a part of the of the post-Bretton Woods period.

\section{Combination of Monetary Commitments}

While there is considerable variation in the choice of individual monetary institutions, the central focus of this volume is to explain the combination of monetary institutions chosen. If $\mathrm{CBI}$ and fixed exchange rates represent solutions to the problem of time-inconsistency in monetary policy, one might expect some type of correlation in the propensity to adopt these institutions. For example, if these institutions are substitutes, countries that have chosen one commitment mechanism

12. It is likely that the continued propensity to peg the exchange rate in these regions is due to Optimal Currency Area (OCA) considerations. For more on the OCA framework, see the following section. 
TABLE 2. Monetary regimes after 1973

Share of time with a pegged exchange rate

\begin{tabular}{|c|c|c|}
\hline $\begin{array}{l}\text { Central bank } \\
\text { independence }\end{array}$ & Below median & Above median \\
\hline Above median & $\begin{array}{l}16 \text { countries including Switzerland, } \\
\text { United States, Mexico, and South } \\
\text { Africa ( } 22.2 \text { percent of sample) }\end{array}$ & $\begin{array}{l}19 \text { countries including Austria, } \\
\text { Netherlands, Taiwan, and Malaysia } \\
(26.4 \text { percent of sample })\end{array}$ \\
\hline Below median & $\begin{array}{l}20 \text { countries including United } \\
\text { Kingdom, Japan, Brazil, and South } \\
\text { Korea ( } 27.8 \text { percent of sample) }\end{array}$ & $\begin{array}{l}17 \text { countries including Belgium, } \\
\text { Sweden, Venezuela, and Thailand } \\
\text { (23.6 percent of sample) }\end{array}$ \\
\hline
\end{tabular}

Note: Countries were classified as "above median" in central bank independence if they were below the developing country sample median in turnover rate or above the developed country sample median in legal independence. Countries were classified as above the sample median (.60) in share of time with a pegged exchange rate.

may be less inclined to adopt the other. On the other hand, if each of these institutions mitigates, but does not definitively solve, the time-inconsistency problem, we might expect countries that had one commitment mechanism to also choose the other. In the former case, we would expect the adoption of these institutions to be negatively correlated; in the latter, we would expect them to be positively correlated. In fact, variations in the pattern of monetary commitments support neither case.

Table 2 provides a sense of this variation in a sample of seventy-six countries since 1973. Each cell contains the number of countries that conformed to a particular combination of monetary institutions, a few representative examples, and the fraction of the sample in each category. A glance at the table shows the combination of monetary institutions varies widely. Countries with a dependent central bank have allowed the exchange rate to float throughout much of the period (for example, the United Kingdom or Brazil) and have fixed the exchange rate for long periods (for example, Sweden or Thailand). Countries that delegated policy to an independent central bank have also pursued a variety of exchange rate options; Switzerland, the United States, Mexico, and South Africa have floating exchange rates, while Austria, the Netherlands, Taiwan, and Malaysia pegged their exchange rates for long periods of the sample. The cell percentages indicate that the combination of monetary commitments is distributed almost equally across all four categories.

Table 2 is a cross-sectional snapshot of the combination of monetary institutions. There is also considerable intertemporal variation in the paths of monetary reform across countries. That is, countries have moved from one set of monetary institutions to a different combination of monetary institutions in a variety of patterns and 
at very different times. A few examples illustrate these different processes. During the 1970s and 1980s, Britain had a dependent central bank and a floating exchange rate; the Conservative government declined to join the EMS when it was founded in 1979. After renewed inflation in the late 1980s, Britain experimented with fixed exchange rates by joining the EMS in 1990. That commitment, however, soon became untenable, and Britain was forced to allow the pound to float after the September 1992 currency crisis. In 1997, British politicians granted the Bank of England substantially more autonomy in setting interest rate policy. Starting from a similar combination of monetary institutions in the 1970s, France followed a different path. France was a founding member of the EMS. As that exchange-rate commitment hardened in the 1980s, France moved to support the single currency and also granted its central bank independence in 1993.

While substantial declines in legal CBI have been exceedingly rare in recent years, an examination of turnover rates in developing countries suggests that it would be wrong to infer that there has been a worldwide increase in de facto independence. For example, South Korea, which frequently floated its currency, and Egypt, which frequently maintained a peg, both exhibit evidence of a decline in behavioral CBI during the 1980s. Both countries had turnover rates well below the developing country median in the earlier period, but in the 1980 s, they changed central bank heads about once every two (Korea) or three years (Egypt). In contrast, Greece, which has allowed its currency to float for much of the period, and Honduras, which maintained a peg for almost the entire period, cut their turnover rates in half in the same period-doubling the "life expectancy" of the central bank head.

Such variance in outcomes is difficult to explain if these institutions are implemented simply as a mechanism for producing universally desired economic outcomes. The combination of the different reforms remains a puzzle to be explained. Why do some countries choose both CBI and fixed exchange rates? Why do some countries adopt neither commitment device? Of those countries that do adopt a single commitment device, what explains why some countries choose an external constraint, while others choose a domestic one? In the following section, we review economic explanations for the choice of monetary institutions, emphasizing that these questions cannot be adequately addressed unless the analyst is willing to examine both institutions simultaneously. In one way or another, each contributor to this volume attempts to do just that.

\section{The Economics of Monetary Institutions}

An established literature examines the benefits and costs of monetary institutions from the perspective of a benevolent social planner. However, normative analyses of central bank and exchange-rate institutions have evolved as largely separate fields of study, resulting in two highly specialized and distinct literatures on optimal monetary institutions. In this section, we abstract from the differences to illustrate 
the common theoretical elements that bind the literatures together. In so doing, we make a case for treating the two institutions as jointly determined.

\section{Time-Inconsistency and the Logic of Delegation}

Since price instability (high inflation and inflation variability) generates a variety of welfare-reducing distortions, the maintenance of price stability is one of the core desiderata of normative macroeconomics. ${ }^{13}$ A surprising result in modern macroeconomics is that even benevolent social planners have difficulty producing price stability when they have direct control of monetary policy. The reason is grounded in the time-inconsistency problem. ${ }^{14}$

Dynamic inconsistency arises when a policy announced for some future period is no longer optimal when it is time to implement the policy. The problem occurs in monetary policy when policy is set with discretion and wages and prices are not fully flexible. Under these conditions, a policymaker may try to fool private actors by inflicting an inflationary surprise after these actors have locked into wage and price contracts on the basis of expectations of low future inflation. The policymaker's incentive to do so ex post lies in her preference for raising output and employment above its natural level, which is possible at least temporarily when wages and prices are sticky. ${ }^{15}$ Failure to do so would not be rational given the utility function of the policymaker. However, when private agents are equally rational and forward-looking, they anticipate this incentive and take it into account when forming their ex ante inflationary expectations. Rational expectations thus introduce an inflationary bias into wage bargaining and price setting at an earlier stage of the game. Consequently, when the policymaker adopts surprise inflation, the equilibrium outcome is higher inflation but not higher output and employment. Frustrated in the effort to engineer a boost in output, the best the policymaker can hope for is to attain a low inflation goal. But to do so requires a credible commitment to refrain from the attempt to stimulate output after wages and prices are set.

Delegation schemes constitute important institutional devices to enhance credibility. Delegating monetary policy to an independent central bank staffed with officials that are more averse to inflation than the government can be a source of credibility. ${ }^{16}$ If the private sector believes that the central banker is conservative (that is, places a greater weight on low inflation than on output and employment) and independent of government (that is, cannot be pressured to depart from its preannounced policy of low inflation), then inflationary expectations are kept in check and

13. Garfinkel 1989.

14. See Kydland and Prescott 1977; and Barro and Gordon 1983.

15. The "natural" rate of employment is the rate that would occur in the absence of monetary disturbances. The Non-Accelerating Inflation Rate of Unemployment (NAIRU) is a related concept. Monetary surprises may have temporary "real" effects-that is, effects on output and employmentwhen the inflation generated exceeds the nominal growth fixed in wagesetters' and pricesetters' contracts.

16. Rogoff 1985; and Neumann 1991. 
actual inflation is on average lower and more stable than in the discretionary equilibrium.

Delegating monetary policy to a conservative foreign central bank via a pegged exchange rate is another way to enhance credibility. ${ }^{17}$ While the traditional case for stable exchange rates hinges on the benefits of increased foreign trade and investment (see following), recent analyses tend to place more emphasis on credibility issues and the role of fixed regimes in stabilizing inflation expectations. ${ }^{18}$ With roots in the rational expectations literature, this work builds on the same time-inconsistency problem described previously. Pegging the exchange rate to the currency of a low-inflation nation provides a strong constraint on the conduct of domestic monetary policy, thereby enhancing the credibility of the government's commitment to price stability. ${ }^{19}$ With a fixed regime, monetary policy must be subordinated to the requirements of maintaining the peg, effectively "tying the hands" (eliminating the discretion) of the domestic policymakers. By pegging, the nation adopts the monetary policy of the foreign central bank, and in so doing "borrows" its credibility to supplement its own. Both forms of institutional delegation can in theory help resolve the time-inconsistency problem. ${ }^{20}$ But this alone does not explain the conditions under which these institutions are chosen because both institutions require trade-offs between increased price stability and other economic policy goals. In light of these trade-offs, the choice of these institutions is a political questioneven if the primary motivation is to solve the technocratic sounding problem of time-inconsistent monetary policy.

One important trade-off shared by both institutions is between credibility and flexibility. In principal, CBI and pegged exchange rates can each be effective in enhancing the credibility of governments' commitment to low inflation. This is an important benefit to national welfare, but the benefit comes with a reduction in the capacity of policymakers to stabilize the domestic economy. Delegation to a conservative central bank, for example, forces a trade-off between lower inflation and output stabilization; the more conservative the central banker, the less she stabilizes output in the face of unanticipated disturbances, especially supply shocks like oil crises. ${ }^{21}$ Indeed, a central bank can be too conservative in fighting inflation, causing excessive volatility in economic activity. ${ }^{22}$ But efforts to increase the flexibility of monetary policy may compromise the very credibility of the central bank's commitment to low inflation. This is because wagesetters have difficulty

17. Giavazzi and Giovannini 1989.

18. For example, Canavan and Tommasi 1997; and Giavazzi and Pagano 1988.

19. Mishkin 1999.

20. Empirically, the evidence is stronger with respect to the credibility effects of fixed exchange rates. Ghosh et al. 1997 analyzed 136 countries over a 30-year period and found that pegging is indeed associated with lower inflation. The evidence on the effect of CBI on inflation is less consistent. See also de Haan and Kooi 2000; and Eijffinger and de Haan 1996. These inconsistent findings may be due to the fact that the effectiveness of CBI in lowering inflation is conditioned by the political environment in which it is found-a theme developed systematically in this volume.

21. For example, Lohmann 1992.

22. Debelle and Fischer 1994. 
disentangling a "legitimate" stabilization effort from an act of opportunism, given the wide array of factors that affect money demand and velocity and the various lags through which monetary policy is transmitted to the economy. Although various solutions to the problem have been proposed, the trade-off remains an important consideration in delegating policy to a domestic central bank. ${ }^{23}$

Pegging the exchange rate poses a similar trade-off. To gain the benefits of greater credibility, governments must sacrifice their capacity to run an independent monetary policy. The "unholy trinity" principle explains that, where capital is internationally mobile, a fixed rate and monetary independence are not simultaneously attainable. $^{24}$ Instead, a country must give up one of three goals: exchange-rate stability, monetary independence, or financial market integration. When capital is mobile internationally, domestic interest rates cannot long differ from world interest rates, as capital flows induced by arbitrage opportunities quickly eliminate the differential. A fixed exchange rate with international capital mobility renders monetary policy ineffective, meaning that there is no leeway to use monetary policy for demand management or balance of payments adjustment. This constraint poses a trade-off between the competing values of credibility and flexibility not unlike that which arises with CBI.

\section{Exchange-Rate Commitments and Optimal Currency Areas}

Fixing the exchange rate can be a substantial benefit for economies that have had difficulty controlling inflation. Exchange-rate stability can also yield gains for economies that are heavily internationalized. This is the principal insight of the OCA approach to exchange-rate regime choice. ${ }^{25}$ From this perspective, the main advantage of a fixed rate regime is to lower the exchange-rate risk and transaction costs that can impede international trade and investment. ${ }^{26}$ Volatile exchange rates create uncertainty about international transactions, adding a risk premium to the costs of goods and assets traded across borders. While it is possible to hedge against this risk in derivatives markets, hedging invariably involves costs that increase with the duration of the transaction. And recent experience indicates that there is a great deal of unexplained volatility in currency markets, which makes hedging particularly difficult for small countries' currencies. By opting to stabilize the currency, a government can reduce or eliminate exchange-rate risk, and so encourage greater

23. In Lohmann 1992, the government, at a cost, can overrule the conservative central banker. This accountability produces a superior policy in which the central banker responds more strongly to large shocks than to small ones. This partially resolves the trade-off problem because it leaves room for policy to perform a stabilization role. In a similar vein, Walsh 1993 and 1995 shows that a "contract" between the government and the central bank tying the central banker's remuneration to inflation performance can attain efficiency. The contract removes the inflationary bias of policy but still allows the central banker's counter-cyclical policy to be optimally active. The incentive for political principals to enforce such a contract, however, remains open to question.

24. Mundell 1962 and 1963.

25. See Tavlas 1994; and Eichengreen 1995.

26. See Mundell 1961; McKinnon 1962; and Kenen 1969. 
trade and investment - a desirable objective quite distinct from the credibility gains of pegging. Going the next step to a currency union does away with the remaining transaction costs, providing an even stronger impetus to economic integration. ${ }^{27}$

But what unites the credibility and the OCA approaches is the elemental trade-off in economic goals: pegging means foregoing domestic monetary flexibility. Achieving exchange-rate stability at the expense of such flexibility can be a substantial cost for countries that face severe shocks to which monetary policy might be the appropriate response. Indeed, the advantages of floating reduce to the single crucially important property that it allows a government to have its own independent monetary policy. Under a full float, demand and supply for domestic currency against foreign currency are balanced in the market. There is no obligation or necessity for the central bank to intervene. Therefore, domestic monetary aggregates do not need to be affected by external flows, and a monetary policy can be pursued that is independent of, and does not need to have regard for, monetary policy in other countries. This policy autonomy is valuable since it provides flexibility to accommodate foreign and domestic shocks, including changes in the external terms of trade and interest rates. More generally, floating allows monetary policy to be set autonomously, as deemed appropriate in the domestic context (for example, for stabilization purposes), and the exchange rate becomes a residual, following whatever path is consistent with the stabilization policy.

A related advantage of floating is that it allows the exchange rate to be used as a policy tool. This flexibility is valuable when real appreciation, caused by inertial inflation or rapid capital inflows, harms international competitiveness and threatens to generate a balance of payments crisis - this is a common syndrome in developing and transition economies that use a fixed exchange rate as a nominal anchor for credibility purposes. ${ }^{28}$ When residual inflation generates an inflation differential between the pegging country and the anchor, it induces a real appreciation that, without compensating productivity gains, leads to balance-of-payments problems. A more flexible regime allows policymakers to adjust the nominal exchange rate to ensure the competitiveness of the tradable goods sector. However, the more flexible the regime, the smaller the credibility gains. The trade-off between credibility and competitiveness is particularly relevant in countries where inflation has been a persistent problem. ${ }^{29}$

Table 3 summarizes the relevant trade-offs as they relate to delegation via CBI and fixed exchange rates. The credibility/flexibility trade-off underpins the social welfare approach to both central banking and exchange rate institutions: CBI and pegging both yield credibility but require reductions in the ability to stabilize output

27. Time-series studies of the relationship between exchange-rate volatility and trade or investment typically find small, weak negative effects. Frankel 1995. However, much stronger effects are evident in cross-sectional evaluations; countries that share a common currency (or have a long-term peg) trade more than three times as much as comparable countries that have separate currencies. See also Rose 2000.

28. Edwards and Savastano 1999.

29. Frieden, Ghezzi, and Stein 2001. 
TABLE 3. Welfare effects of alternative monetary delegation schemes

\begin{tabular}{lll}
\hline Benefits & Costs \\
\hline $\begin{array}{c}\text { Central bank } \\
\text { independence }\end{array}$ & $\bullet$ Credibility $\Rightarrow$ lower inflation & $\bullet$ Monetary inflexibity $\Rightarrow$ less stabilization \\
$\begin{array}{c}\text { Fixed exchange } \\
\text { rates }\end{array}$ & $\begin{array}{l}\bullet \text { Credibility } \Rightarrow \text { lower inflation } \\
\text { Exchange rate stability } \Rightarrow \text { more trade } \\
\text { and capital flows }\end{array}$ & $\begin{array}{l}\bullet \text { Monetary inflexibility } \Rightarrow \text { less stabilization } \\
\text { with competitiveness }\end{array}$ \\
\hline
\end{tabular}

and employment. This trade-off poses a theoretical puzzle; why do some countries opt to delegate domestically to a conservative central bank while others utilize pegs to a foreign currency (or some other fixed regime) for credibility purposes? OCA considerations relate only to exchange-rate regime choice and raise the caution that credibility is not the only, or perhaps not even the most important, factor influencing the choice of monetary institutions. ${ }^{30}$ Indeed, for very small, highly trade-dependent economies such as the island nations of the Caribbean, the decision to peg is over-determined by OCA considerations. ${ }^{31}$ For these countries, enhanced credibility is merely a by-product of the force of such factors. Yet for economies that are neither so small nor so open that pegging is the obvious option, the question as to the choice of monetary institutions remains salient. For example, the regions of the EMU do not satisfy OCA criteria, and few suggest that Argentina belongs in a currency union with the United States. Credibility motivations evidently swamp OCA considerations in certain contexts. Untangling the relative explanatory importance of these forces is a central concern of many contributors to this volume.

From the perspective of welfare economics, which institution is best for a particular country is largely a matter of the economic characteristics of the country. The trade-off between the credibility of monetary policy pronouncements and the flexibility to stabilize output may be steeper in countries with a greater exposure to output shocks. The trade-off between exchange-rate stability and trade shocks will be steepest in economies that depend heavily on trade in a small number of goods markets. Since large numbers of countries with similar economic characteristics have chosen different combinations of monetary institutions, however, such an explanation is unsatisfying. Consequently, the authors in this volume stress the ways political factors influence the choice and combination of institutions. Some do so by emphasizing the ways the economic trade-offs discussed previously are politically and institutionally conditioned. Others relax the assumption that institutions are chosen by a benevolent social planner and argue that they are chosen for primarily

30. Frieden 2002.

31. Obstfeld and Rogoff 1995. 
political reasons but are conditioned by factors highlighted by the time-inconsistency or OCA frameworks.

\section{First- and Second-Generation Work on Monetary Institutions}

The economic logic of monetary delegation is explicitly apolitical. That is, the classic time-inconsistency problem is analyzed from the perspective of a benevolent planner whose objectives coincide with maximizing social welfare. The temptation to engineer an inflationary surprise comes from the desire to raise national income and, thereby, increase social welfare. While this makes a "hard case" for the existence of time-inconsistency problems, it also makes the decision to adopt an institutional fix trivial. Because benevolent social planners also care about reducing inflation, they would obviously adopt an institution that allows them to overcome the time-inconsistency problem. But political actors who possess goals that need not be consistent with the good of society make decisions about monetary policy institutions. A body of positive political economy research that we label the "first generation" departs from the benevolent social planner assumption and incorporates various political incentives and constraints that shape governments' decisions on monetary institutions. However, this work follows the economics literature by considering CBI and exchange-rate regimes as isolated, unrelated outcomes.

In this next section, we briefly review these first-generation approaches to the choice of monetary institutions. We also demonstrate how the second-generation contributions of this volume highlight and extend these different approaches. While each contribution emphasizes a different mechanism to explain the pattern of monetary commitments, each explicitly considers the simultaneous choice of CBI and exchange-rate regime.

Political economy arguments to explain the choice of monetary institutions fall into two broad classes: those that focus on "policy suppliers"-politicians and political parties-and those that focus on "policy demanders"-interest groups, economic sectors, and voters. Within each of these approaches, political economists have developed a number of mechanisms to explain either CBI or the exchange rate regime. But almost without exception, analysts have chosen to examine the choice of these institutions in isolation. Whether the focus has been on policy suppliers or policy demanders, political economists have not explored the conditional or concurrent choice of these two institutions.

\section{Policy Suppliers and the Choice of Monetary Commitments}

Politicians in office obviously do not have to delegate monetary policy authority to a conservative central bank, domestic or foreign. When they do so, it is because delegation serves their purposes. The credibility/flexibility trade-off provides a simple framework for analyzing how politicians weigh the benefits and costs of 
granting more independence to a central bank. ${ }^{32}$ Delegation to an independent and inflation-averse central bank at home or abroad serves as a commitment device to circumvent the time-inconsistency problem and resulting inflationary bias. The most prominent cost is that the government in office loses monetary policy flexibility. The incumbent government has less capacity to engage in stabilization policy via monetary instruments.

When politicians consider this trade-off, they do so within constraints imposed by their political environment. Five arguments potentially link the incentives of policy suppliers to exchange-rate regimes and $\mathrm{CBI}$ : welfare gains, constraining future governments, policymaking capabilities, electoral opportunism, and government partisanship. The articles in this volume draw on the latter three mechanisms to analyze the choice of monetary commitments.

Social welfare benefits. One strand of literature suggests that monetary commitments will provide greater social welfare gains where political pressures discourage responsible monetary and fiscal policies. In situations where governments face pressures to adopt lax macroeconomic policies, the value of these monetary commitments - in terms of superior economic outcomes-is higher. As a result, politicians who face inflationary pressures will be more likely to adopt a fixed exchange rate as a nominal anchor ${ }^{33}$ or an independent central bank. ${ }^{34}$ This type of argument suggests that countries with weak and unstable governments will be more likely to adopt monetary commitments, since these governments are unable to carry out stabilization programs. ${ }^{35}$ High public debt and high levels of unemployment also increase the inflationary pressures on governments and, according to this logic, increase the propensity to adopt monetary commitments. Tests of these hypotheses produce only mixed results. Using a sample of the industrial democracies, Jakob De Haan and Gert Jan Van't Hag for example, find no relationship between CBI and government turnover, public debt, or the equilibrium employment rate. ${ }^{36}$

Constraining future governments. Another set of arguments contends that political actors recognize how monetary commitments can lock in the policy preferences of the enacting coalition, tying the hands of future politicians. ${ }^{37}$ Susanne

32. For example, Cukierman 1994; and Broz and Frieden 2001.

33. See Flood and Isard 1989; Giavazzi and Pagano 1988; and Rogoff 1985.

34. See Franzese 1999; de Haan and Van't Hag 1995; Alesina 1988; and Cukierman 1992. Other research indicates that the macroeconomic consequences of monetary commitments depend on labor market organization. See Hall and Franzese 1998; Franzese 1999 and 2002; Iversen 1999 and 1998; and Soskice and Iversen 1998. According to the literature, monetary commitments reduce inflation most where wage bargaining is least coordinated. These commitments tend to increase unemployment, but at a diminishing rate where wage bargaining is more highly coordinated. These arguments suggest that the overall benefits of a monetary commitment may be greatest when wage bargaining is moderately coordinated.

35. See Alesina 1987; and Cukierman 1992.

36. de Haan and Van't Hag 1996.

37. McCubbins, Noll, and Weingast 1989. 
Lohmann, for instance, argues that political parties were engaged in a "turf battle" during the Bundesbank's founding, trying to choose institutions that would protect their ability to affect policy in the future. ${ }^{38}$ John Goodman argues that politicians will choose an independent central bank to insulate policy from future opposition governments, especially from parties with a high-inflation policy program. ${ }^{39}$ Delia Boylan identifies conditions under which outgoing autocrats will attempt to constrain the policy choices of democratic successors by enhancing the independence of the central bank. ${ }^{40}$ These types of arguments imply a government will choose a monetary commitment if subsequent governments are likely to possess different policy priorities. In systems where policy change is incremental across governments, politicians have fewer incentives to make an institutional commitment since they can trust subsequent governments to pursue similar policies. In a cross-national test of CBI, William Bernhard finds no support for such an argument. ${ }^{41}$

Political capacity. A third set of arguments focuses on the policymaking capabilities of the government to explain monetary commitments: policymakers will not adopt a monetary institution unless they have the ability to ensure the success of that commitment. Weak or unstable governments may lack the ability to implement the difficult domestic adjustments often necessary to sustain a fixed exchange rate. ${ }^{42}$ Strong, durable governments are able to pursue the policies required to maintain the exchange rate and, therefore, are more likely to adopt an exchange-rate commitment.

Related arguments suggest that politicians will adopt an independent central bank only where they can credibly commit to maintaining that institutional arrangement. Since the existence of many veto players in the policy process will help prevent politicians from overturning the policy actions of an independent central bank, these arguments suggest that independent central banks will be more likely in systems with many veto players. In contrast, CBI can be overturned easily in systems with few veto players. ${ }^{43}$ Consequently, politicians will be less likely to pay the short-term costs of adopting an independent central bank.

In the current volume, the papers by Philip Keefer and David Stasavage and by Mark Hallerberg make extensive use of the veto-player framework. ${ }^{44}$ Keefer and Stasavage investigate how the number of veto players affects the credibility of monetary commitments. They argue that delegation to an independent central bank will be more credible than low-inflation-policy pronouncements when multiple governmental veto players are present. Any low-inflation policy implemented by an independent central bank can be overridden by a single veto player. In contrast, low-

38. Lohmann 1998 and 1994.

39. Goodman 1991.

40. Boylan 2001.

41. Bernhard 1998.

42. See Eichengreen 1992; and Simmons 1994.

43. Moser 1999.

44. See Keefer and Stasavage 2002; and Hallerberg 2002. 
inflation policies may survive the displeasure of a subset of political principals if at least one veto player prefers the banks' policy to the policy that would be enacted by a government with discretionary power over monetary policy. Keefer and Stasavage argue that this logic does not extend to exchange-rate commitments because the policy outcome expected under a peg to a low-inflation currency is likely to be seen as prohibitively austere by even the most hawkish domestic actors. Instead, they argue that exchange-rate pegs reduce inflation because they help solve the problem of asymmetric information in monetary policy. By analyzing the choice of both monetary institutions in a common framework, they reach the conclusion that these institutions are not alternative solutions to the same problem, but rather solve two different problems faced by incumbents. As such, their study demonstrates the advantage of a "second-generation" approach.

Hallerberg also emphasizes the role of veto players in the choice of monetary commitments, but he is not primarily interested in their effect on the credibility of commitments. Instead, he argues that the existence of veto players influences the identifiability and controllability of monetary and fiscal policy. Identifiability and controllability determine whether incumbents will choose to use monetary or fiscal policy for electoral purposes, which-in a world of mobile capital-influences their assessments of the various possible combinations of exchange-rate regime and CBI. For example, Hallerberg argues that the existence of subnational veto players in federal systems makes controlling fiscal policy difficult. As a consequence, actors in these systems will shun pegged exchange rates in an attempt to preserve monetary policy autonomy. Conversely, the divisibility of fiscal policy makes it more attractive than monetary policy as a political instrument in the hands of multiparty coalitions. Consequently, governments comprised of many partisan veto players are more likely to peg the exchange rate than single-party governments. This last result is consistent with Bernhard and David Leblang's ${ }^{45}$ finding of a link between proportional representation and an increased propensity to peg, but is potentially at odds with Keefer and Stasavage's assertion that increasing the number of veto players appears to decrease the credibility of pegged exchange rates. ${ }^{46}$

Political opportunism. A standard assumption in political science is that politicians and parties are office-seeking, that is, that they desire to remain in office. Politicians, then, may use monetary policy surprises to generate temporary expansions in employment and growth just prior to an election. ${ }^{47}$ Delegating monetary policy to an independent central bank or fixing the exchange rate, however, limits politicians' discretion over monetary policy. Indeed, William Clark and Usha Reichert ${ }^{48}$ find that these monetary commitments limit opportunistic political business cycles. ${ }^{49}$

45. Bernhard and Leblang 1999.

46. Keefer and Stasavage 2002.

47. Nordhaus 1975.

48. Clark and Reichert 1998.

49. See also Clark and Hallerberg 2000. 
Drawing on these insights, political economists have argued that the "electoral value" of monetary policy will shape the choice of monetary institutions. Where the control of monetary policy may strongly shape electoral outcomes, politicians will be less likely to sacrifice flexibility by adopting an independent central bank or a fixed exchange rate. The electoral value of monetary policy will reflect the time horizon of politicians ${ }^{50}$ or the configuration of domestic political institutions. ${ }^{51}$ According to Bernhard and Leblang, in systems where the costs of losing an election are high or if small shifts in voter support can lead to large swings in the distribution of seats, politicians will be reluctant to give up control over any policy instrument that can help them win elections. Consequently, they will be less likely to adopt a fixed exchange rate (or, by implication, an independent central bank). In systems where the costs of being in opposition are lower or where a small loss in votes does not necessarily lead to exclusion from government, politicians may be more likely to adopt a monetary commitment. In contrast, Clark argues that, if incumbents can use fiscal policy to respond to electoral pressures, monetary commitments need not frustrate their attempt to use the macroeconomy for political purposes. ${ }^{52}$

Clark's contribution to this volume examines whether politicians subject to electoral pressures have as much incentive to find a cure for the inflationary bias of discretionary monetary policy as the benevolent social planners in the standard time-inconsistency setup. ${ }^{53} \mathrm{He}$ finds that, to a large extent, they do. In addition, he shows that the magnitude of such pressures can play an important role in determining whether incumbents will solve the problem by pegging the exchange rate or by delegating policy monetary policy to an independent central bank. The credibility of the independent central bank also influences the rate of substitution between these monetary institutions. Clark argues that the extent to which survival-maximizing incumbents view fiscal policy as a close substitute for monetary policy is also likely to influence the choice between monetary institutions.

Government partisanship. Other analysts examine how government partisanship affects the choice of monetary commitments. According to the partisanship literature, parties have different policy objectives, which reflect the interests of their key supporters. ${ }^{54}$ Left parties appeal to the working class and, thus, emphasize employment and wealth redistribution as policy goals. Reflecting business and middle-class interests, Right parties are more concerned with controlling inflation. Assuming that an independent central bank and an exchange-rate peg provide enhanced antiinflation credibility, the most straightforward link implies that Right parties will be

50. See Goodman 1991; and Cukierman and Webb 1995.

51. See Bernhard and Leblang 1999; and Leblang 1999.

52. Clark forthcoming.

53. Clark 2002.

54. See Alesina and Sachs 1989; Hibbs 1977 and 1987; and Havrilesky 1987. 
more likely to support these commitments. ${ }^{55}$ In contrast, other authors turn this logic on its head. Left parties may recognize that they lack anti-inflation credibility and, in turn, favor monetary commitments as a way to demonstrate their commitment to responsible economic policies. ${ }^{56}$ Since Right parties already have a reputation for price stability, they have little need to support these monetary commitments to gain credibility and prefer to see discretionary monetary policy remain grounds for political competition with the Left.

Tests of the partisan arguments on the choice of monetary commitments have produced only mixed results. Bernhard finds no relationship between partisanship and the cross-national variation of CBI in the 1970s and 1980s. ${ }^{57}$ Moreover, both Right and Left parties initiated central bank reform in the 1980s and 1990s. ${ }^{58}$ A number of authors find that Left parties were more likely to support exchange commitments, both during the interwar years ${ }^{59}$ and in the EMS experience. ${ }^{60}$ Another study of developed countries in the post-Bretton Woods period, however, found no relationship between partisanship and exchange-rate regime choice. ${ }^{61}$

Political parties, however, can use the political credibility of an independent central bank to appeal to constituents with diverse policy preferences and to prevent any intra-party disputes over monetary policy from precipitating a cabinet collapse. ${ }^{62}$ These types of arguments suggest that monetary commitments will be more likely in systems where political parties must maintain diverse electoral and legislative coalitions.

The contribution by Bernhard and Leblang provides a test of this argument. ${ }^{63}$ The authors contend that increased economic openness in the industrial democracies has heightened the potential for intra-party conflicts over economic and monetary policy, hurting the ability of parties to remain in office. Monetary commitments can help manage these policy conflicts and keep parties in office. They test the effect of $\mathrm{CBI}$ and exchange-rate commitments on cabinet durability in sixteen parliamentary democracies. The results indicate that these monetary institutions can increase cabinet durability, especially for coalition governments. By exploring the choice of both exchange-rate regime and $\mathrm{CBI}$ in a single paper, they are able to examine the relative effectiveness of alternative monetary institutions in solving the survival problems faced by incumbents.

55. See, for example, Goodman 1991 on central banks; Simmons 1994; and Oatley 1997 on exchangerate commitments.

56. See Milesi-Ferritti 1995; and Garrett 1995.

57. Bernhard 1998.

58. Bernhard 2002.

59. See Simmons 1994; and Eichengreen 1992.

60. See Garrett 1995; and Oatley 1997.

61. Bernhard and Leblang 1999.

62. Bernhard 2002.

63. Bernhard and Leblang 2002. 


\section{Policy Demanders and the Choice of Monetary Commitments}

The second approach to explaining the variation in monetary institutions focuses on policy demanders: sectoral interests, interest groups, and voters. This approach is premised on the idea that monetary institutions have distributional implicationswhat is optimal for a country as a whole may not be optimal for particular groups within a country. The distributional consequences of these institutions, therefore, represent part of the explanation of their causes.

Anti-inflation interests. The array of anti-inflation interests in society might include retirees on non-indexed fixed incomes, institutional bondholders, elements of the financial sector, and even the mass public in situations where hyperinflation or sustained high inflation remains part of the collective consciousness. ${ }^{64}$ Adam Posen, for instance, argues that the demands and organization of such societal interests will determine the level of $\mathrm{CBI} .{ }^{65} \mathrm{He}$ contends that central banks will take a strong anti-inflation stance only when there is a coalition of interests politically capable of protecting it. The behavior of the central bank depends on the existence of a coalition of inflation hawks in society politically capable of supporting the central bank when it faces informal (non-statutory) pressures to inflate. There is some support for the hypothesis that central banks are more independent in countries where anti-inflationary social interests are powerful. ${ }^{66}$

Broz's argument about the choice of monetary institutions echoes a similar logic. ${ }^{67} \mathrm{He}$ begins with the assumption that all societies contain low-inflation constituencies; what varies is the extent to which these actors are able to verify a government's commitment to a credibility-enhancing monetary institution. In democracies, low-inflation actors are relatively able to monitor governmental activities, which enhances the credibility of a monetary commitment. But in autocracies, the lack of political-system openness undermines the monitoring capabilities of inflation hawks; governmental promises are less verifiable and, therefore, less credible.

Monetary commitments also differ in terms of verifiability. ${ }^{68}$ Broz expects credibility-seeking autocratic governments to opt for fixed exchange rates because fixing offers the verifiability that autocratic promises lack. Democracies, by contrast, are likely to find legal CBI credible. Even though it is a less verifiable commitment, anti-inflationary interests have the capacity to detect and punish informal (non-legislative) governmental efforts to violate the independence of the central bank in democracies. Indirect monitoring by inflation hawks thereby enhances credibility. The structure of political institutions, therefore, conditions the choice of monetary institutions.

64. See Hibbs 1982, 1985; and Issing 1993.

65. Posen 1995.

66. See Posen 1995; and de Haan and Van 't Hag 1995.

67. Broz 2002.

68. For example, Frankel, Schmukler, and Serven 2000. 
Broz's argument shares some aspects of the political capacity approach: governments chose monetary institutions with an eye toward their effectiveness in resolving the time-inconsistency problem. Broz's contribution, however, illustrates the links between political system characteristics, the incentives and actions of demandside social actors, and the effectiveness of alternative monetary institutions.

Broz also demonstrates the value of a second-generation approach. First-generation scholars posited an unconditional relationship between the goals of antiinflation social actors and the demand for CBI or fixed exchange rates. Broz shows that anti-inflationary interests benefit from CBI only when political institutions are sufficiently transparent. When this is not the case, social actors that benefit from price stability are likely to pin their hopes on fixed exchange rates.

Economic sectors. Other authors emphasize the distributional consequences across economic sectors to account for different monetary commitments. In an influential article, Jeffry Frieden identifies how social groups align on the trade-off between global integration and monetary-policy flexibility in the choice of exchange-rate regime. ${ }^{69}$ Groups heavily involved in foreign trade and investment (producers of exportables, foreign direct and portfolio investors, and international merchants) should favor fixed exchange rates, since currency volatility makes their business riskier and more costly. By contrast, groups whose economic activity is confined to the domestic economy benefit from a floating regime due to the monetary flexibility that floating allows. Producers in the nontradables sector (for example, services, construction, and transport) belong in this camp because they are largely insulated from foreign markets but are highly sensitive to domestic macroeconomic conditions.

Building on this argument, Frieden develops a demand-side account of exchangerate regime choice by focusing on the movement toward monetary integration in the EU. ${ }^{70}$ Frieden argues that the trade-off between greater trade and investment (lower left cell in Table 3, above) and lost currency flexibility (lower right cell in Table 3) was critical in animating interest groups on the issue of stabilizing European exchange rates. With modest refinements to earlier arguments, Frieden posits that cross-border investors and exporters of specialized manufactured goods should be strong advocates of fixed rates; import competers, on the other hand, should oppose fixing since this sector suffers from the loss of ability to adjust currency values to enhance competitiveness. Frieden takes pains to develop reasonable proxies for interest-group variables to test the argument statistically-an important achievement given the difficulty of measuring group preferences and political influence.

Frieden's contribution represents an explicit challenge to the credibility arguments that dominate the rest of this volume (as well as to the OCA arguments that are common in the literature on Europe). Regime choice, Frieden cautions, may 
have more to do with the politics of real outcomes (trade and investment) than purely monetary goals. The empirical results in his contribution consolidate the firstgeneration research program and point the way for second-generation work on the sectoral determinants of the choice of monetary institutions. An examination of how the institutional demands of inflation-averse actors interact (Broz) with demands for particular exchange-rate regimes by sectoral actors concerned primarily about their international competitiveness (Frieden) would be a promising future extension of this work.

\section{Conclusion}

We have sought to accomplish three goals in our introduction to this volume. First, we described the range of institutional outcomes that the contributors of the volume hope to explain. Since the breakup of Bretton Woods, countries have been confronted with the choices of whether to peg their exchange rates and whether to grant their central banks independence. Decisions along these two dimensions produce four ideal typical regimes (see Table 2), and countries in both the developed and developing world have sustained institutional combinations that approximate each ideal type.

Second, we reviewed the argument that $\mathrm{CBI}$ and pegged exchange rates represent alternative solutions to the problem of time-inconsistent monetary policy. We argue that, while time-inconsistency is certainly a key factor in the choice of monetary institutions, the wide variety of combinations of monetary institutions observed cannot be simply explained as technological solutions to the inflationary bias inherent in discretionary monetary policy. Why are monetary commitment "technologies" not universally adopted? And if they were, what determines which solution would be chosen in a particular context?

Finally, we have sought to summarize the answers provided to these questions by the contributors to this volume. Briefly, the authors in this volume argue that the particular political context influences the extent to which (1) politicians are induced to pursue goals that compete with price stabilization or (2) they are inhibited from successfully implementing monetary commitments. Electoral, partisan, or sectoral pressures may loom larger than price stabilization goals for incumbents. Political institutions may condition the extent to which these pressures influence incumbents. These political institutions may also inhibit or facilitate the ability of incumbents to convey credible commitments to CBI or pegged exchange rates.

In sum, the authors in this volume argue that, even if adopting pegged exchange rates or granting CBI is desirable because it reduces the inflationary bias of discretionary policy, an explanation of the range of observed institutional outcomes requires an inquiry into the price paid for their adoption. In particular, if fixed exchange rates and CBI are potential substitutes, it is vital that we gain an understanding of their relative prices. For this reason, the contributors simultaneously consider the determinants of both types of monetary commitments. In doing 
so, they offer new answers to existing questions and provoke debates that open up vistas for future research. The benefits of this "second-generation" approach include the following:

- Clark identifies the ways in which the magnitude of political pressures and the credibility of monetary commitments interact to influence the rate of substitution between CBI and fixed exchange rates.

- Keefer and Stasavage show that domestic veto players influence the credibility of commitments to $\mathrm{CBI}$, but not the credibility of commitments to pegged exchange rates.

- Hallerberg finds that federalism reinforces commitments to CBI, but not to pegged exchange rates. ${ }^{71}$

- Bernhard and Leblang demonstrate that, in a world of global capital mobility, CBI and exchange-rate commitments are alternative means that coalition governments can use to address the problem of political survival.

- By finding that CBI may make it easier for governments to sustain a pegged exchange rate, Frieden suggests these institutions may be complements.

- Broz shows that, when the absence of transparency reduces the credibility of $\mathrm{CBI}$, it increases the propensity to peg the exchange rate, suggesting that these institutions are substitutes.

Clearly, there is much second-generation work to be done, but the contributors in this volume get the research program off to a roaring start.

In the volume's conclusion, John Freeman highlights important features of the papers and sets an agenda for a "third generation" of research into the politics of monetary commitments. ${ }^{72}$ Freeman notes that the contributions to the volume share a common assumption about the important role of monetary technocracy in shaping economic performance. He argues that, as a whole, the volume begins to show how democratic institutions can be designed to "create and protect" a sphere for socially benign technocratic expertise in the management of monetary policy. The authors show how democracy "fits" with allegedly "undemocratic" monetary commitments. He states that the articles in the volume represent a significant contribution in that they emphasize the interaction of political and economic forces in theoretically sophisticated and nuanced ways.

At the same time, however, Freeman challenges the field of international political economy to start work on a new generation of theoretical models and empirical tests that will uncover new facts about the relationships among democratic processes, institutions, and economic performance. This new generation of research should encompass work on the microfoundations of economic and political equilibria, a

71. In fact, federal countries with multiparty systems are less likely to peg than unitary systems.

72. Freeman 2002. 
broader understanding of the welfare criteria used to evaluate institutional arrangements, and a deeper analysis of the economic consequences of political information.

The contributors to this volume do not reach a consensus regarding the factors that determine the choice of monetary institutions. While they agree that political factors are crucial, important differences remain about the precise mechanisms by which politics affects the choice of monetary institutions. Readers must evaluate the logic and evidence for the competing claims. It is our hope that this work is a consolidation, rather than the culmination, of a program for theoretically informed, empirically grounded research on the determinants of monetary institutions.

\section{References}

Alesina, Alberto. 1987. Macroeconomic Policy in a Two-Party System as a Repeated Game. Quarterly Journal of Economics 102 (3):651-78.

. 1988. Macroeconomics and Politics. In NBER Macroeconomics Annual, vol. 3, 13-52.

Cambridge, Mass.: NBER and MIT Press.

Alesina, Alberto, and Jeffrey Sachs. 1988. Political Parties and the Business Cycle in the United States. Journal of Money, Credit, and Banking 20 (1):63-82.

Alesina, Alberto, and Lawrence Summers. 1993. Central Bank Independence and Macroeconomic Performance: Some Comparative Evidence. Journal of Money, Credit, and Banking 25 (2):151-62.

Barro, Robert, and David B. Gordon. 1983. Rules, Discretion, and Reputation in a Model of Monetary Policy. Journal of Monetary Economics 12 (1):101-21.

Bernhard, William. 1998. A Political Explanation of Variations in Central Bank Independence. American Political Science Review 92 (2):311-28.

. 2002. Banking on Reform: Political Parties and Central Bank Independence in the Industrial Democracies. Ann Arbor: University of Michigan Press.

Bernhard, William, and David Leblang. 1999. Democratic Institutions and Exchange-Rate Commitments. International Organization 53 (1):71-97.

- 2002. Political Parties and Monetary Commitments. International Organization 56 (4):803-30.

Boylan, Delia M. 1998. Preemptive Strike: Central Bank Reform in Chile's Transition from Authoritarian Rule. Comparative Politics 30 (4):443-62.

. 2001. Defusing Democracy: Central Bank Autonomy and the Transition from Authoritarian Rule. Ann Arbor: University of Michigan Press.

Broz, J. Lawrence. 2002. Political System Transparency and Monetary Commitment Regimes. International Organization 56 (4):861-87.

Broz, J. Lawrence, and Jeffry A. Frieden. 2001. The Political Economy of International Monetary Relations. Annual Review of Political Science 4:317-43.

Burdekin, Richard C. K., and Thomas D. Willett. 1991. Central Bank Reform: The Federal Reserve in International Perspective. Public Budgeting and Financial Management 3 (3):619-49.

Calvo, Guillermo A., and Carmen M. Reinhart. 2000. Fear of Floating. Unpublished manuscript. College Park, Md.: University of Maryland.

Canavan, Chris, and Mariano Tommasi. 1997. On the Credibility of Alternative Exchange-Rate Regimes. Journal of Developmental Economics 54 (1):101-22.

Clark, William Roberts. 2002. Partisan and Electoral Motivations and the Choice of Monetary Institutions Under Fully Mobile Capital. International Organization 56 (4):725-49.

- Forthcoming. Capitalism, not Globalism: Capital Mobility, Central Bank Independence, and the Political Control of the Economy. Ann Arbor: University of Michigan Press.

Clark, William Roberts, Usha Nair Reichert, Sandra Lynn Lomas, and Kevin L. Parker. 1998. International and Domestic Constraints on Political Business Cycles in OECD Economies. International Organization 52 (1):87-120. 
Clark, William Roberts, and Mark Hallerberg. 2000. Mobile Capital, Domestic Institutions, and Electorally Induced Monetary and Fiscal Policy. American Political Science Review 94 (2):323-46.

Cukierman, Alex. 1992. Central Bank Strategy, Credibility and Independence: Theory and Evidence. Cambridge, Mass: MIT Press.

- 1994. Commitment through Delegation, Political Influence, and Central Bank Independence. In A Framework for Monetary Stability: Paper and Proceedings of an International Conference Organised by De Nederlandsche Bank and the Center for Economic Research at Amsterdam, edited by J. Onno De Beaufort Wijnholds, Sylvester C. Effinger and Lex H. Hoogduin, 55-74. Dordrecht: Kluwer Academic Publishers.

Cukierman, Alex, Steven B. Webb, and Bilin Neyapti. 1992. Measuring the Independence of Central Banks and Its Effect on Policy Outcomes. World Bank Economic Review 6 (3):353-98.

Cukierman, Alex, and Steven B. Webb. 1995. Political Influence on the Central Bank: International Evidence. World Bank Economic Review 9 (3):397-423.

Cukierman, Alex, Geoffrey P. Miller, and Bilin Neyapti. 2001. Central Bank Reform, Liberalization and Inflation in Transition Economies - An International Perspective. Working Paper 19. Tel Aviv University: Foerder Institute for Economic Research.

de Haan, Jakob, and Willem Kooi. 2000. Does Central Bank Independence Really Matter? New Evidence for Developing Countries Using a New Indicator. Journal of Banking and Finance 24 (4):646-64.

de Haan, Jakob, and Gert Jan Van 't Hag. 1995. Variation in Central Bank Independence Across Countries: Some Provisional Empirical Evidence. Public Choice 85 (3-4):335-51.

Debelle, Guy, and Stanley Fischer. 1994. How Independent Should the Central Bank Be? In Goals, Guidelines, and Constraints Facing Monetary Policymakers, edited by Jeffrey C. Fuhrer, 195-221. Boston: Federal Reserve Bank of Boston.

Edwards, Sebastian, and Miguel A. Savastano. 1999. Exchange Rates in Emerging Economies: What Do We Know? What Do We Need to Know? NBER Working Paper 7228. Cambridge, Mass.: National Bureau of Economic Research.

Eichengreen, Barry. 1992. Should the Maastricht Treaty Be Saved? Princeton Studies in International Finance, No. 74. Princeton, N.J.: Princeton University.

- 1995. The Endogeneity of Exchange Rate Regimes: The Macroeconomics of the Open Economy. In Understanding Interdependence, edited by Peter Kenen, 3-33. Princeton, N.J.: Princeton University Press.

Eijffinger, S. C. W., and Jakob de Haan. 1996. The Political Economy of Central Bank Independence. Special Papers in International Economics 19. Princeton, N.J.: Economics Department, Princeton University.

Flood, Robert P. and Peter Isard. 1989. Monetary Policy Strategies. International Monetary Fund Staff Papers. 36 (3):612-32.

Frankel, Jeffrey A. 1995. Monetary Regime Choice for a Semi-Open Economy. In Capital Controls, Exchange Rates and Monetary Policy in the World Economy, edited by Sebastian Edwards, 35-69. New York: Cambridge University Press.

Frankel, Jeffrey, Sergio Schmukler, and Luis Serven. 2000. Verifiability and the Vanishing Intermediate Exchange Rate Regime. NBER Working Paper 7901. Cambridge, Mass.: National Bureau of Economic Research.

Franzese, Robert J. 1999. Partially Independent Central Banks, Politically Responsive Governments, and Inflation. American Journal of Political Science. 43 (3):889-910.

2. 2002. Macroeconomic Policies of Developed Countries. New York: Cambridge University Press.

Freeman, John. M. 2002. Competing Commitments: Technocracy and Democracy in the Design of Monetary Institutions. International Organization 56 (4):889-910.

Frieden, Jeffry A. 1991. Invested Interests: The Politics of National Economic Policies in a World of Global Finance. International Organization 45 (4):425-51.

- 2002. Real Sources of European Currency Policy: Sectoral Interests and European Monetary Integration. International Organization 56 (4):831-60. 
Frieden, Jeffry A., Pierro Ghezzi, and Ernesto Stein, 2001. Politics and Exchange Rates: A CrossCountry Approach. In The Currency Game: Exchange Rate Politics in Latin America, edited by Jeffry Frieden and Ernesto Stein, 21-64. Washington, D.C.: Inter-American Development Bank.

Garfinkel, Michelle R. 1989. What is the 'Acceptable' Rate of Inflation? Federal Reserve Bank of St. Louis Review 71 (4):3-15

Garrett, Geoffrey. 1995. Capital Mobility, Trade, and the Domestic Politics of Economic Policy. International Organization 49 (4):657-87.

Ghosh, Atish R., Anne-Marie Gulde, Jonathan D. Ostry, and Holger C. Wolf. 1997. Does the Nominal Exchange Rate Regime Matter? NBER Working Paper 5874. Cambridge, Mass.: National Bureau of Economic Research.

Giavazzi, Francesco, and Alberto Giovannini. 1989. Limiting Exchange Rate Flexibility: The European Monetary System. Cambridge, Mass.: MIT Press.

Giavazzi, Francesco, and Marco Pagano. 1988. The Advantage of Tying One's Hands: EMS Discipline and Central Bank Credibility. European Economic Review 32 (5):1055-82.

Goodman, John B. 1991. The Politics of Central Bank Independence. Comparative Politics 23 (3):32949.

Grilli, Vittorio, Donato Masciandaro, and Guido Tabellini. 1991. Political and Monetary Institutions and Public Financial Policies in the Industrial Countries. Economic Policy 13 (October):342-92.

Hall, Peter A., and Robert Franzese. 1998. Mixed Signals: Central Bank Independence, Coordinated Wage-Bargaining, and European Monetary Union. International Organization 52 (3):505-35.

Hallerberg, Mark. 2002.Veto Players and the Choice of Monetary Institutions. International Organization 56 (4):775-802.

Havrilesky, Thomas M. 1987. A Partisanship Theory of Fiscal and Monetary Regimes. Journal of Money, Credit, and Banking 19 (3):308-25.

Hibbs, Douglas A., Jr., 1977. Political Parties and Macroeconomic Policy. American Political Science Review 71 (4):1467-87.

- 1985. Inflation, Political Support and Macroeconomic Policy. In The Politics Of Inflation And Economic Stagnation: Theoretical Approaches and International Case Studies, edited by Leon Lindberg and Charles Maier, 175-95. Washington, D.C.: Brookings Institution.

- 1987. The Political Economy of Industrial Democracies. Cambridge, Mass: Harvard University Press.

Hibbs, Douglas A., Jr., R. Douglas Rivers, and Nicholas Vasilatos. 1982. On the Demand for Macroeconomic Outcomes: Macroeconomic Performance and Mass Political Support in the United States, Great Britain and Germany. The Journal of Politics 44 (2):426-62.

Issing, Otmar. 1993. Central Bank Independence and Monetary Stability. Occasional Paper 89. London: Institute of Economic Affairs.

Iversen, Torben. 1998. Wage Bargaining, Central Bank Independence, and the Real Effects of Money. International Organization 52 (3):469-504.

-1999. Contested Economic Institutions: The Politics of Macroeconomics and Wage Bargaining in Advanced Democracies. Cambridge: Cambridge University Press.

Keefer, Philip, and David Stasavage. 2002. Checks and Balances, Private Information, and the Credibility of Monetary Commitments. International Organization 56 (4):751-74.

Kenen, Peter. 1969. The Theory of Optimum Currency Areas. In Monetary Problems of the International Economy, edited by Robert A. Mundell and Alexander K. Swoboda, 41-60. Chicago: University of Chicago Press.

Kydland, Finn E., and Edward C. Prescott. 1977. Rules Rather Than Discretion: The Inconsistency of Optimal Plans. Journal of Political Economy 85 (3):473-86.

Leblang, David. 1999. Democratic Political Institutions and Exchange Rate Commitments in the Developing World. International Studies Quarterly 43 (4):599-620.

Lohmann, Susanne. 1992. Optimal Commitment in Monetary Policy: Credibility Versus Flexibility. American Economic Review 82 (1):273-86. 
1994. Designing a Central Bank in a Federal System: The Deutsche Bundesbank, 1957-1992. In Varieties of Monetary Reforms: Lessons and Experiences on the Road to Monetary Union, edited by Pierre Siklos, 247-78. Boston: Kluwer Academic Press.

1998. Federalism and Central Bank Independence: The Politics of German Monetary Policy, 1957-92. World Politics 50 (3):401-46.

Maxfield, Sylvia. 1997. Gatekeepers of Growth: The International Political Economy of Central Banking in Developing Countries. Princeton, N.J.: Princeton University Press.

McCubbins, Matthew D., Roger G. Noll, and Barry R. Weingast. 1989. Structure and Process, Politics and Policy: Administrative Arrangements and the Political Control of Agencies. Virginia Law Review 75 (2):431-82.

McKinnon, Ronald I. 1963. Optimal Currency Areas. American Economic Review. 53 (4):717-25.

Milesi-Ferretti, Gian Maria. 1995. The Disadvantage of Tying Their Hands: On the Political Economy of Policy Commitments. Economic Journal 105 (433):1381-402.

Mishkin, Frederic S. 1999. International Experiences with Different Monetary Policy Regimes. NBER Working Paper 6965. Cambridge, Mass.: National Bureau of Economic Research.

Moser, Peter. 1999. Checks and Balances and the Supply of Central Bank Independence. European Economic Review 43 (8):1569-93.

Mundell, Robert A. 1961. A Theory of Optimum Currency Areas. American Economic Review 51 (4):657-65.

1962. The Appropriate Use of Monetary and Fiscal Policy for Internal and External Stability. IMF Staff Papers 9 (1):70-9.

. 1963. Capital Mobility and Stabilization Policy under Fixed and Flexible Exchange Rates. The Canadian Journal of Economics and Political Science 29 (4):475-85.

Neumann, Manfred J.M. 1991. Precommitment by Central Bank Independence. Open Economies Review 2 (1):95-112.

Nordhaus, William D. 1975. The Political Business Cycle. Review of Economic Studies 42 (2):169-90.

Oatley, Thomas. 1997. Monetary Politics: Exchange Rate Cooperation in the European Union. Ann Arbor: University of Michigan Press.

Obstfeld, Maurice, and Kenneth Rogoff. 1995. The Mirage of Fixed Exchange Rates. Journal of Economic Perspectives 9 (4):73-96.

Posen, Adam. S. 1995. Declarations are Not Enough: Financial Sector Sources of Central Bank Independence. NBER Macroeconomic Annual 10:253-74.

Rogoff, Kenneth. 1985. The Optimal Degree of Commitment to an Intermediate Monetary Target. Quarterly Journal of Economics 100 (4):1169-90.

Rose, Andrew. 2000. One Money, One Market: Estimating the Effect of Common Currencies on Trade. Economic Policy 30:7-46.

Simmons, Beth A. 1994. Who Adjusts? Domestic Sources of Foreign Economic Policy During the Interwar Years, 1924-1939. Princeton, N.J.: Princeton University Press.

Soskice, David, and Torben Iversen. 1998. Multiple Wage-Bargaining Systems in the Single European Currency Area. Oxford Review of Economic Policy 14 (3):110-24.

Tavlas, George. 1994. The Theory of Monetary Integration. Open Economies Review 5 (2):211-30.

Walsh, Carl E. 1993. Central Bank Strategies, Credibility, and Independence. Journal of Monetary Economics 32:287-302.

—. 1995. Optimal Contracts for Central Bankers. American Economic Review 85 (1):150-67. 